DOI https://doi.org/10.18551/rjoas.2017-08.18

\title{
ANALYSIS OF QUALITY CONTROL IN SEPAKU PETUNG ROAD IMPROVEMENT THROUGH RIGID PAVEMENT BY PT BONE BORNEO
}

\author{
Bestaraya Buen*, Hidayat Sutanto, Wedyantadji Bambang \\ Study Program of Civil Engineering, Concentration of Construction Management, \\ National Institute of Technology, Malang, Indonesia \\ *E-mail: buenbest@gmail.com
}

\begin{abstract}
This research aims were to: analyze the effect of factors on the performance of quality control in rigid pavement project, implement an action by reducing the possibility of quality failure and minimize the effect if it's truly happen as the effort to increase project's quality performance. This research was using qualitative approach. This research used questionnaire distributed to each respondent so that responses to the problems studied in the research were obtained. Research result showed that the factors were: used material, broken material, wrong decision, the numbers of blue-collar workers, skill level of workforce, the numbers of executor, distribution of workforce, assignment, the numbers of equipment, communication between parties, design error, project scheduling, damage by third party, specifications difficult to understand, and strict project schedule. To prevent the decrease of quality performance in a project, material control should be done, as well as the stages of project implementation in order to be in accordance with the work plan. Contractor should be observant in making decision about everything related to the project. Contractor should be able to consider all of the aspects that could affect the quality performance of the project. Besides, the project design should be right and designed carefully from the material element up to the workforce.
\end{abstract}

\section{KEY WORDS}

Quality control, project, road improvement, rigid pavement.

Construction project is one of a series of activity that is interrelated and has a particular objective. The objective that wants to be achieved in a construction project is able to realize the project activity effectively and efficiently with limited budget, quality, and time. This causes precision in quality, implementation method, and time allocation becomes a must for Contractor Company in realizing a project. Control should be done from the exploration of project's realization possibility, project's appropriateness, planning, implementation, until the operation and the maintenance of the project. Besides that, successful project realization is also affected by the correct management of the project (Gaspersz, 2001).

Road is the main supporting element in a development, so that its quality should be good and allows the vehicles to pass on it safely and comfortably. However, there are still many examples of low quality road project result, and are not in accordance with the requirement. Damages are happening, even though it's not yet the time. In the implementation of the project (including the maintenance), quality incompatibility can still be found, so that the road should be repaired and treated; and of course this needs more budget. In the broader definition, "quality" is subjective. Something that has good quality for someone is not necessarily the same for the others (Crosby, 1979). Therefore, business world and industry tries to give some limitations that could be accepted by the interested parties (ISO 8402, 1986).

Quality is the primary need in a construction project. This time, quality is no longer defined as traditional meaning as a conformance of a requirement, but as a product that could satisfy the consumer (Harvey and Green, 1993). When a construction project is in progress, various stages that should be passed such as initiation, planning, execution, control, and closing are not escaping from quality management so that an optimal output can be produced. Stages in quality control in order to keep on the predefined standards, become 
the most important emphasize for the construction project's sustainability. The stages are: in the planning stage it needs a quality planning procedure, in the implementation stage it needs a quality reassurance, in the evaluation stage it needs a quality control, and also maintenance and quality improvement stages. Quality control is the most important thing to do in a construction project (Latif, 2009).

Quality of the construction project is highly affected by the used material, used equipment, skillful human resources, good planning, and strict control during the implementation until the project is finished, so that the expected quality could be achieved. The research object is rigid pavement improvement of Sepaku-Petung that lies on the North Panajam Paser Regency, East Kalimantan Province. In the implementation of rigid pavement project in Sepaku-Petung, the researcher observe all of the process, and see if any rigid becomes porous or cracked due to the decrease of quality. Some conjectures from some parties involved in this rigid work is the choice of material, and the stages of implementation which is not appropriate with the procedures that have been established. The decrease of quality makes the contractor to spend more budgets to repair and treat the damaged rigid.

The problems studied in this research are: 1) what factors affect the quality performance of rigid pavement project by PT Bone Borneo?, 2) What action should be done in the implementation of rigid pavement project in order to increase the quality performance?

This research aims are: 1) to analyze the factors that affect the quality performance of rigid pavement project, and 2) to do an action of reducing the possibility of quality failure and minimize the effect if that failure truly happen, in order to increase the project's quality performance.

\section{METHODS OF RESEARCH}

This research used quantitative research approach. This research used questionnaire distributed to each respondent so that responses about the problems studied in this research were obtained (Arikunto, 2006). Analysis of the research data was done through statistical testing with IBM SPSS Statistics 20.

\section{RESULTS AND DISCUSSION}

Simultaneous Test of Hypothesis (F Test). To know the significance of independent variable simultaneously on a dependent variable, F Test could be used (Gay \& Diehl, 1992). The result of simultaneous test of hypothesis by using IBM SPSS Statistics 20 can be seen in Table 1.

Table 1 - Simultaneous Test of Hypothesis

ANOVA $^{a}$

\begin{tabular}{|l|l|l|l|l|l|l|}
\hline \multicolumn{1}{|c|}{ Model } & \multicolumn{1}{c|}{ Sum of Squares } & df & \multicolumn{1}{c|}{ Mean Square } & \multicolumn{1}{c|}{ Sig. } \\
\hline \multirow{2}{*}{1} & Regression & 61.797 & 5 & 12.359 & 31.637 & $.000^{\mathrm{b}}$ \\
\cline { 2 - 8 } & Residual & 10.939 & 28 & 391 & & \\
\cline { 2 - 6 } & Total & 72.735 & 33 & & & \\
\hline
\end{tabular}

a. Dependent Variable: $Y$

b. Predictors: (Constant), X5, X2, X4, X1, X3

Based on the data shown in Table 1, it can be known that the $F$ value is 31,637 . The $F$ table value was on significance level of $5 \%$ and degree of freedom (df) as much as $k=2-1$, while the denominator degree of freedom (df2) as much as $n-k(34-1=33)$ is 4,14 . If these two values are compared with the $F$ value, the result is bigger than $F$ table value $(31,637>4,14)$ so that $\mathrm{HO}$ was rejected. Therefore, it could be concluded that five independent variables (material, contractor, implementation method, condition in field, and drawing plan) are simultaneously and very significantly affect the dependent variable (quality performance). Besides, it can be seen from the significance value that is below $0.05(0,000)$. 
Partial Test of Hypothesis ( $T$ test). To know which variables that have partial effect on the dependent variable, regression coefficient test was done by using statistical $\mathrm{T}$ test. The determination of test result (acceptance / rejection of $\mathrm{H} 0$ ) could be done by comparing the values of $\mathrm{t}$-count and t-table and also from the significance value.

Table 2 - Partial Test of Hypothesis

Coefficients $^{a}$

\begin{tabular}{|c|c|c|c|c|c|c|c|}
\hline \multirow{2}{*}{ Model } & \multicolumn{2}{|c|}{ Unstandardized Coefficients } & \multirow{2}{*}{$\frac{\text { Standardized Coefficients }}{\text { Beta }}$} & \multirow[b]{2}{*}{$\mathrm{t}$} & \multirow{2}{*}{ Sig. } & \multicolumn{2}{|c|}{ Collinearity Statistics } \\
\hline & $\mathrm{B}$ & Std. Error & & & & Tolerance & VIF \\
\hline (Constant) & .244 & 694 & & 351 & .728 & & \\
\hline $\mathrm{X} 1$ & 102 & .029 & .512 & 3.525 & .023 & 225 & 4.452 \\
\hline $\mathrm{X} 2$ & .161 & .067 & .371 & 2.400 & .001 & 255 & 3.925 \\
\hline $\mathrm{X} 3$ & -.146 & 057 & -.406 & -2.547 & 017 & 212 & 4.727 \\
\hline $\mathrm{X} 4$ & .057 & .027 & 203 & 2.105 & .044 & 577 & 1.734 \\
\hline $\mathrm{X} 5$ & .141 & .049 & .363 & 2.894 & .007 & 341 & 2.931 \\
\hline
\end{tabular}

a. Dependent Variable: $Y$

Based on Table 2, t-table value from each variable can be seen. To make a decision about acceptance or rejection of $\mathrm{HO}$, the values of t-table should be determined. This value depends on the degree of freedom (df) and the significance level that is used. By using significance level of $5 \%$ and df value as much as n-k-1 (34-6-4=29), the t-table obtained was 1,699. The test result of each independent variable $(X 1, X 2, X 3, X 4$, and $X 5)$ on the dependent variable $(Y)$ are as follows.

The Effect of Material (X1) on the Quality performance ( $Y$ ). Based on Table 2, it can be seen that the t-count value was 3,525. If the value is compared to the t-table value of 1,699 ; the value of $\mathrm{t}$-count is far greater than the value of $\mathrm{t}$-table so that $\mathrm{HO}$ was rejected. Therefore, it could be concluded that material variable was affecting the quality performance significantly. This can also be seen through the significance value of $\mathrm{X} 1$ that is smaller from 0,05 ; that is $0,023<0,05$.

The Effect of Contractor (X3) on the Quality performance (Y). Based on Table 2, it can be seen that the t-count value was 2,400 . If the value is compared to the t-table value of 1,699 ; the value of $\mathrm{t}$-count is far greater than the value of $\mathrm{t}$-table so that $\mathrm{HO}$ was rejected. Therefore, it could be concluded that contractor variable was affecting the quality performance significantly. This can also be seen through the significance value of X2 that is smaller from 0,05; that is $0,001<0,05$.

The Effect of Implementation Method (X3) on Quality performance (Y). Based on Table 2 , it can be seen that the $t$-count value was 2,542 . If the value is compared to the $t$-table value of 1,699; the value of t-count is far greater than the value of t-table so that $\mathrm{H} 0$ was rejected. Therefore, it could be concluded that implementation method variable was affecting the quality performance significantly. This can also be seen through the significance value of $\mathrm{X} 3$ that is smaller from 0,05 ; that is $0,017<0,05$.

The Effect of Field Condition (X4) on the Quality performance (Y). Based on Table 2, it can be seen that the t-count value was 2,105 . If the value is compared to the t-table value of 1,699 ; the value of $\mathrm{t}$-count is far greater than the value of $\mathrm{t}$-table so that $\mathrm{HO}$ was rejected. Therefore, it could be concluded that field condition variable was affecting the quality performance significantly. This can also be seen through the significance value of X4 that is smaller from 0,05; that is $0,045<0,05$.

The Effect of Drawing plan (X5) on the Quality performance (Y). Based on Table 2, it can be seen that the t-count value was 2,894 . If the value is compared to the t-table value of 1,699; the value of $\mathrm{t}$-count is far greater than the value of $\mathrm{t}$-table so that $\mathrm{H} 0$ was rejected. Therefore, it could be concluded that drawing plan variable was affecting the quality performance significantly. This can also be seen through the significance value of X5 that is smaller from 0,05; that is $0,007<0,05$. 


\section{DISCUSSION OF RESULTS}

Factors Affecting the Quality performance of Rigid Pavement Project. Roadwork projects have different characteristics from building projects, where field conditions are elongated, in an open environment, and have uneven contours. The geological condition of the work site is a risk factor of the implementation (Asmarantaka, 2014). Aspects that may affect a quality (implementation of construction projects) include: human resource, working methods, machinery/equipment, materials, and environment. Every construction project implementation is unique because it cannot be separated from the influence of geographical factors that exist in the project site environment, whether technical or non-technical. Problems related to technical matters, for example in the establishment of foundation structures in relation to local soil conditions and structures. While the example of things related to non-technical issues are: regulations and permits, the state of habitat, climate and weather (Latief et al., 2009).

Decrease in quality performance can be caused by several factors, including materials, contractors, methods of implementation, field conditions, and drawing plans. If supplier's stock of the material in is empty or the supplier does not have the stock of material ordered it will certainly affect the quality performance of the project. In addition to the material, the second factor is the contractor. Decisions taken by contractors should not be wrong as they will affect the quality performance of a project. The third factor is the implementation method. These factors include the order of implementation, the number and also the type of equipment. If the equipment used is not in accordance with the project being done it will affect the quality performance of a project. The fourth factor is the field condition. These field conditions include design errors, weather, and communication between parties, project scheduling, and damage by third party, data distribution, coordination flow, and commitment. Of those eight factors, the factor that has most effect in the field is the lack of communication between parties and errors in project design. The fifth factor is the plan drawing variable. The most influential factor in this variable is the image specification that is not easily understood so that is difficult to be implemented.

Each of the factors causing the decrease of project quality performance in those five categories has almost the same weight. This almost equal weight means that all factors can have the same impact and do not rule out more than one factor that causes a decrease in quality performance in a project. Based on simultaneous hypothesis test of this research, it can be proved that the five factors have an effect on to quality performance in rigid pavement road project. This can be proven from the $F$ value that is greater than the $F$ table of each variable. Besides of $F$ count value, it can also be seen from the significance value. From the research results, the significance value obtained was $<0.05$, so that it was proven that the five variables are simultaneously affect the quality performance in rigid pavement road project.

The Most Dominant Factor that Affect the Quality performance of Rigid Pavement Project. The quality performance of a project is influenced by several factors. Factors affecting project quality performance are divided into five variables. These factors have different percentage of weights in affecting project's quality performance. The percentage of each factor on project quality performance can be seen in Table 3 .

Based on Table 3, it can be seen that there is one factor that is most dominant in influencing project quality performance. The most dominant factor is found in the material variable, which is material used factor. This factor has the highest percentage value compared to other factors that is worth $91,7 \%$. The most dominant factor is included in the material variable.

Material is one of the variables affecting the quality of Sepaku-Petung road improvement project in East Kalimantan Province. If the material is very bad it will greatly affect the quality in a project, but if the material is good then it will increase the quality of the project. This material has four factors in which one of the factors is the dominant factor in influencing the quality of Sepaku-Petung road improvement project in East Kalimantan Province. This factor includes the material used to work on this project. Based on the factor 
analysis, the value of the material factor used has an effect of 0.917 on the quality performance of the construction of Sepaku-Petung road improvement project in East Kalimantan Province. If the material used is not good then the quality of construction performance will not be good as well. This can be proven from the component matrix value of the material factor used, that is as much as 0.917 .

Table 3 - Component Matrix that Affects the Quality performance

\begin{tabular}{|c|l|c|}
\hline \multicolumn{1}{|c|}{ Variable } & \multicolumn{1}{|c|}{ Indicator } & Component Value \\
\hline \multirow{4}{*}{ Material } & Used Material & .917 \\
\cline { 2 - 3 } & Damaged Material & .882 \\
\cline { 2 - 3 } & Material arrival & .806 \\
\hline \multirow{4}{*}{ Contractor } & Personal Competency & .770 \\
\cline { 2 - 3 } & Job Divisions & .765 \\
\cline { 2 - 3 } & Wrong Decision & .621 \\
\cline { 2 - 3 } & Distribution of Workforce & .887 \\
\hline \multirow{4}{*}{ Implementation Method } & The Number of Equipment & .773 \\
\cline { 2 - 3 } & Bad Setup of Site Layout & .755 \\
\cline { 2 - 3 } & Too Many Overtime & .722 \\
\cline { 2 - 3 } & The Type of Equipment & .860 \\
\hline Field Condition & Wrong Design & .895 \\
\hline Drawing Plan & Specifications Not Easily Understood & \\
\hline
\end{tabular}

The Cause of Declining Quality in Rigid Pavement Project. Rigid pavement road project is different from flexible pavement road project. Rigid pavement road project also has several types that the contractor must understand. In addition, the contractor must understand what materials are needed on a rigid pavement road project. The necessary facilities and infrastructure must also be appropriate. If the contractor is wrong in making decisions during the project, it will result in slow progress of the project, and it will not be finished on target. The project will take a long time to be finished. In addition, the quality of the resulting road will not in accordance with expectations or the results will not be satisfying. In addition to these two things the possible impact is the possibility of work accidents due to lack of K3 management. Viewed from the perspective of cost, there is the possibility that there may be cost swelling from various aspects in rigid pavement road projects. Therefore, if the risk cannot be overcome it will result in decreased quality performance of rigid pavement road project.

Management to Reduce the Effect of Declining Quality in Rigid Pavement Project. Project is a set of interconnected activities. There are certain starting points, endpoints, and results. Projects are usually cross-organizational functions that require a variety of skills from various professions and organizations. Each project is unique, and not even two projects are exactly alike. Project is a temporary activity of personnel, materials, and a means to make/realize the project objectives within a certain period of time which then ends (PT Pembangunan Perumahan, 2003). If the activities of project objectives are constrained or there are factors that inhibit or lead to decreased quality performance of a project, strategies should be developed to minimize the inhibiting factors. One way to reduce the impact of factors that trigger a decrease in the quality performance of a project is by choosing the right type of materials. The contractor should be able to provide good quality materials in order to obtain excellent quality. In addition, the design of a project should also correct and designed with high accuracy, from material elements to the workforce used. So the quality of project performance will keep increasing and will not decrease.

\section{CONCLUSION}

Based on the research result and data analysis that had been done, it could be concluded that:

From the factor analysis, it could be known that there are 16 factors affecting the quality performance. Those factors were obtained as the result of communality value 
calculation. If the communality value $>70 \%$, then the factor has a big effect on the quality performance in Sepaku-Petung road improvement project, East Kalimantan Province.

From all of the factors that affect the quality performance of rigid pavement project on Sepaku-Petung, East Kalimantan Provice, there is a factor that is the most dominant on quality performance. The most dominant variable was obtained as the result of partial test of hypothesis ( $t$ test), where the variable with highest beta value is the most dominant variable. The most dominant variable on the quality performance of Sepaku-Petung road improvement is the material variable, with beta value as much as 0,512 . Meanwhile, the most dominant factor on quality performance of Sepaku-Petung road improvement project was obtained from component matrix calculation, where the factor with highest component matrix is material factor, which has component matrix of 0,917 . Therefore, it could be concluded that the most dominant variable is material with beta value of 0,512 and the most dominant factor is also on that variable (material) with component matrix value 0 f 0,917 . That factor has more effect on the quality performance of Sepaku-Petung road improvement project, East Kalimantan Province.

From the analysis, it could be known that the most dominant factor on the quality performance is material. This is what should be concerned in order to keep the quality of Sepaku Petung road improvement project. Therefore, to prevent the decline of quality performance, material control should be done as well as the stages of project implementation in order to be in accordance with the work plan. Contractor should be observant in making all decision related to the project. Contractor should be able to consider all aspects that could affect the project's quality performance. Besides that, a project design should be correct and designed carefully from the material element up to the workforce used.

\section{REFERENCES}

1. Arikunto, S. (2006). Prosedur Penelitian Suatu Pendekatan Praktik. Jakarta: Rineka Cipta.

2. Asmarantaka N. S. (2014). Analisis Resiko Yang Berpengaruh Terhadap Kinerja Proyek Pada Pembangunan Hotel Batiqa Palembang. Universitas Sriwijaya.

3. Crosby, P. B. (1979). Quality is Free: The Art of Making Quality Certain. New York: McGraw-Hill.

4. Gaspersz, V. (2001). Metode Analisis Untuk Peningkatan Kualitas. Jakarta: Gramedia Pustaka Utama.

5. Gay, L.R. dan Diehl, P.L. (1992). Researc Methods for Business and Management. New York: MacMillan Publishing Company.

6. Harvey, L., \& Green, D. (1993). Defining quality. Assessment \& evaluation in greater education, 18(1), 9-34.

7. International Organization of Standardization, Quality, 8402: 1986

8. Latief, Y., Abidin, I. S., \& Asa, M. F. (2009). Variabel-variabel Utama dalam Sistem Manajemen Mutu untuk Peningkatan Profitabilitas Jasa Konstruksi Indonesia yang Berpotensi Meningkatkan Gross Domestic Product Sektor Konstruksi, Jurnal Dinamika Teknik Sipil.

9. Nicholas. (2001). Project Management for Business and Technology: Principles Ana Practice, 2nd edition. New Jersey.

10. PT Pembangunan Perumahan, (2003). Buku Referensi untuk Kontraktor Bangunan Gedung dan Sipil. Jakarta.

11. Schwalbe, K. (2004). Information of Technology Project Management, 3th edition, Canada.

12. Nawari, (2010). Analisis Regresi dengan MS Excel 2007 dan SPSS 17. Jakarta:PT. Elex Media Komputindo. 